\title{
Self-incompatibility in Cornus florida
}

\author{
Sandra M. Reed ${ }^{1}$ \\ Floral and Nursery Plants Research Unit, U.S.National Arboretum, Agricultural \\ Research Service, U.S. Department of Agriculture, Tennessee State University \\ Nursery Crop Research Station, 472 Cadillac Lane, McMinnville, TN 37110
}

Additional index words. breeding, pollen tube growth

\begin{abstract}
Low seed set has been reported following self-pollinations of flowering dogwood (Cornus florida L.). The objective of this study was to verify the presence of self-incompatibility in C. florida. 'Cherokee Princess' stigmas and styles were collected 1, 2, 4, 8, 12, 24, 48, and 72 hours after cross- and self-pollinations, stained with aniline blue and observed using a fluorescence microscope. Pollen germinated freely following self-pollinations, but self-pollen tubes grew slower than those resulting from cross-pollinations. By 48 hours after cross-pollination, pollen tubes had reached the bottom of the style while pollen tubes in self-pollinated flowers had only penetrated the upper third of the style. Evidence of reduced pollen tube growth rate in self-pollinations of 'Cherokee Chief' and 'Cherokee Brave' was also obtained. This study provides evidence of a gametophytic self-incompatibity system in $C$. florida. It was also determined that stigmas of $C$. florida 'Cherokee Princess' are receptive to pollen from 1 day prior to anthesis to 1 day after anthesis.
\end{abstract}

The genus Cornus consists of $\approx 50$ species, many of which are cultivated as ornamentals (Dirr, 1998; Eyde, 1988). The most popular member of the genus is $C$. florida, or flowering dogwood, which is highly valued as a landscape tree because of its white, pink or red bracts in the spring, autumn foliage color, and fruit display. According to the 1998 Census of Horticultural Specialties, annual sales of $C$. florida exceeded \$26 million, ranking it third among flowering deciduous trees for U.S. sales. Many cultivars are available in the marketplace, but most have been the result of grower selections of sports or superior seedlings rather than organized plant breeding efforts (Santamour and McArdle, 1985).

In recent years, disease problems have plagued native populations, nursery stock and landscape plantings of $C$. florida (Sherald et al., 1996; Sinclair et al., 1987) and have prompted a search for disease resistant germplasm. A plant with resistance to anthracnose (Discula destructiva) was discovered in the wild and released as the cultivar Appalachian Spring (Windham etal., 1998). Three powdery mildew resistant cultivars have recently been released (Windham et al., 2000) and other resistant individuals identified (Mmbaga and Sheng, 2001); all these plants were selected from seedling populations growing at nurseries. While progress in developing disease resistant cultivars has been made through selection of open-pollinated seedlings, development of cultivars with multiple disease resistance or with a combination of disease resistance and specific ornamental characteristics will most likely require controlled pollinations between selected parents.

Received for publication $23 \mathrm{Dec}$. 2002. Accepted for publication 21 Apr. 2003. Mention of trade names of commercial products in the publication is solely for the purpose of providing specific information and does not imply recommendation or endorsement by the U.S. Dept. of Agriculture.

${ }^{1}$ Research Geneticist.

HortScIENCE, Vol. 39(2), ApriL 2004 freshly dehisced anthers. The flower was then removed from the inflorescence and the fresh pollen touched directly to the stigma of the maternal parent. For self-pollinations, pollen was obtained from a flower on the same plant as the emasculated flower.

Pollen tube staining and observations. Flowers were placed into FAA fixative (18:1:1, $70 \%$ ethanol : formalin : glacial acetic acid) (Johansen, 1940) immediately following collection. After $24 \mathrm{~h}$ at room temperature in fixative, flowers were transferred to $70 \%$ ethanol where they were stored for up to 4 months. Prior to staining, the style was excised at the point of attachment to the ovary and rinsed in distilled water. The style with attached stigma was softened using $8 \mathrm{~N} \mathrm{NaOH}$ for $16 \mathrm{~h}$. The tissue was rinsed in distilled water for $30 \mathrm{~min}$ prior to transfer to $0.1 \%(\mathrm{w} / \mathrm{v})$ aniline blue in $0.1 \mathrm{NK}_{3} \mathrm{PO}_{4}$ for $1 \mathrm{~h}$ (Martin, 1959). The stigma and style were placed on a microscope slide in a drop of stain, squashed under a cover slip, and observed using an Olympus BX-60 microscope (Olympus America, Melville, N.Y.) equipped with a $100-\mathrm{W}$ high-pressure Hg lamp and an U-MNV near-ultraviolet (400-410 nm) filter.

The percentage of stigmas with germinated pollen was recorded for each treatment. Mean number of germinated grains was calculated using only those stigmas on which pollen germination was observed. Because of the difficulty in obtaining an accurate count when large number of grains were present, the following pollen germination rating scale was used: $1=1-25 ; 2=26-50 ; 3=50-75 ; 4=76-100$; and, $5=>100$ germinated pollen grains.

Callose was observed as a yellow-green fluorescence and was used to detect growth of the pollen tubes through the styles. For each style, the length of the three longest pollen tubes was measured using an ocular micrometer. Mean pollen tube length was calculated for each treatment using only those flowers in which pollen germination was observed.

Evaluation of self-incompatibility. Eighty flowers of 'Cherokee Princess' were pollinated $1 \mathrm{~d}$ after emasculation using pollen collected from 'Cherokee Chief'. Eighty flowers of 'Cherokee Princess' were self-pollinated on the same day. Ten cross- and self-pollinated flowers were collected at each of the following times after pollination: 1, 2, 4, 8, 12, 24, 48 , and $72 \mathrm{~h}$. An additional 10 flowers of 'Cherokee Princess' were emasculated but not pollinated; these were collected $24 \mathrm{~h}$ after pollination. Percent stigmas with germinated pollen, mean number of germinated pollen grains, and mean length of pollen tubes were calculated for each treatment.

To confirm results obtained with ' Cherokee Princess' $\times$ 'Cherokee Chief' and self-pollinated 'Cherokee Princess' flowers, 'Cherokee Brave', and 'Cherokee Chief' were also crossand self-pollinated $1 \mathrm{~d}$ after emasculation. 'Cherokee Princess' was used as the pollinator for both sets of cross-pollinations. Ten flowers of each cross- and self-pollination were collected $24 \mathrm{~h}$ after pollination. Pollen tubes were measured, but number of germinated grains were not counted in these samples. 
Breeding, Cultivars, Rootstocks, \& Germplasm Resources

Time of stigma receptivity. Time of stigma receptivity was evaluated over a 5 -d period. Ten 'Cherokee Princess' $\times$ 'Cherokee Chief' pollinations were made on the day of emasculation ( $1 \mathrm{~d}$ prior to anthesis), on the day of anthesis, and 1, 2, and $3 \mathrm{~d}$ after anthesis. Flowers were collected $24 \mathrm{~h}$ after pollination. Percentage of stigmas with germinated pollen, mean number of germinated pollen grains, and mean length of pollen tubes were calculated for each pollination time.

\section{Results and Discussion}

Evaluation of self-incompatibility. Pollen germination was observed on only a few 'Cherokee Princess' stigmas collected 1 to $2 \mathrm{~h}$ after pollination; however, germinating pollen was present on at least $80 \%$ of the stigmas that were collected four or more hours after either cross- or self-pollination (Table 1; Fig. $1 \mathrm{~A}$ and $\mathrm{B}$ ). From 4 to $12 \mathrm{~h}$ after pollination, more germinated grains were observed on stigmas that had been cross-pollinated than on those that had received self-pollen. By $24 \mathrm{~h}$ after pollination, similar numbers of germinated grains were noted on both cross- and self-pollinated stigmas. The number of germinated pollen grains was difficult to determine by 48 $\mathrm{h}$ after pollination due to decreased fluorescence and collapsed appearance of the pollen grains; therefore, counts of germinated grains were omitted for samples collected 48 and $72 \mathrm{~h}$ after pollination. No germinated pollen grains were observed in emasculated, unpollinated controls.

Very few ungerminated pollen grains were observed on any of these stigmas, even in the samples collected 1 to $2 \mathrm{~h}$ after pollination and those that served as the unpollinated control. It appears that ungerminated pollen washed off the stigmas during the fixation or staining procedures. Therefore, it is not known whether the differences in number of germinating grains between self- and cross-pollinations in samples collected 4 to $12 \mathrm{~h}$ after pollination reflect actual differences in pollen germination or were caused by different amounts of pollen being applied to stigmas.

While considerable background fluorescence was observed in C. florida styles, pollen tubes were easily discerned following both cross- and self-pollination. Pollen tubes exhibited fluorescence along their entire length, with brighter callose plugs occasionally apparent (Fig. 1). Differences in pollen tube lengths between 'Cherokee Princess' cross- and self-pollinations were observed in samples collected from 4 to $72 \mathrm{~h}$ after pollination (Fig. 2). From 4 to $24 \mathrm{~h}$ after pollination, pollen tubes of cross-pollinated specimens were about twice the length of those from selfpollinations. By $48 \mathrm{~h}$ after cross-pollination, pollen tubes were observed emerging from the base of the style (Fig. 1D). In contrast, pollen tubes had only penetrated the top one-third of the style in self-pollinations observed 48 $\mathrm{h}$ after pollination. No additional pollen tube elongation was noted in styles collected $72 \mathrm{~h}$ after self-pollination.

Considerable differences in pollen tube

Table 1. Pollen germination on cross- and self-pollinated stigmas of C. florida 'Cherokee Princess' collected $1-72 \mathrm{~h}$ after pollination.

\begin{tabular}{lccc}
\hline Pollination & $\begin{array}{c}\text { Hours after } \\
\text { pollination }\end{array}$ & $\begin{array}{c}\text { Stigmas with } \\
\text { germinated pollen }(\%)^{\mathrm{z}}\end{array}$ & $\begin{array}{c}\text { Mean pollen germination } \\
\text { rating }^{\mathrm{y}}(\text { range })\end{array}$ \\
\hline Cherokee Princess & 1 & 30 & $1.0(1)$ \\
Cherokee Chief & 2 & 20 & $1.0(1)$ \\
& 4 & 90 & $3.0(1-5)$ \\
& 8 & 100 & $3.4(1-5)$ \\
& 12 & 80 & $3.8(1-5))$ \\
Cherokee Princess & 24 & 100 & $2.6(1-4)$ \\
self-pollinated & 48 & 100 & --- \\
& 12 & 100 & --- \\
& 2 & 20 & $1.0(1)$ \\
& 4 & 0 & --- \\
& 8 & 80 & $1.1(1-2)$ \\
& 12 & 80 & $1.6(1-3)$ \\
& 24 & 100 & $2.8(1-3)$ \\
& 48 & 100 & --- \\
\hline
\end{tabular}

${ }^{\mathrm{z}} \mathrm{n}=10$.

${ }^{y}$ Germinated pollen grains: $1=1-25 ; 2=26-50 ; 3=51-75 ; 4=76-100$; and $5=>100$; includes only those flowers in which pollen germination was observed.

length following cross- and self-pollinations of 'Cherokee Chief' and 'Cherokee Brave' were also noted (Fig. 3). As with the 'Cherokee Princess' $\times$ 'Cherokee Chief' pollinations, by $24 \mathrm{~h}$ after pollination pollen tubes had grown about halfway down the styles in the 'Cherokee Chief' $x$ 'Cherokee Princess' and 'Cherokee Brave' $\times$ 'Cherokee Princess' pollinations. At this time, pollen tubes resulting from self-pollinations were only about one-half the length of those from cross-pollinations.

Self-incompatibility is a genetically controlled mechanism that prevents formation of a zygote after self-pollination of a fertile hermaphrodite plant, and is estimated to be present in almost half of all angiosperm species (Brewbaker, 1959). Two homomorphic self-incompatibility systems, sporophytic and gametophytic, are recognized (de Nettancourt,
1977). In the sporophytic self-incompatibility system, the incompatibility reaction is determined by the diploid genotype of the pollen parent and germination of incompatible pollen is inhibited at the stigmatic surface. Gametophytic self-incompatibility is determined by the haploid genotype of the pollen, and is manifested by an inhibition of pollen tube growth in the style. Incompatible pollen tubes generally reach one-third to three-quarters the length of the style in the time required for compatible tubes to penetrate the entire style (Ascher, 1976). Sporophytic self-incompatibility is associated with plants that produce tricellular pollen, whereas gametophytic selfincompatibility is generally found in plants with bicellular pollen (Brewbaker, 1957).

The presence of a self-incompatibility system in C. florida has been suggested by
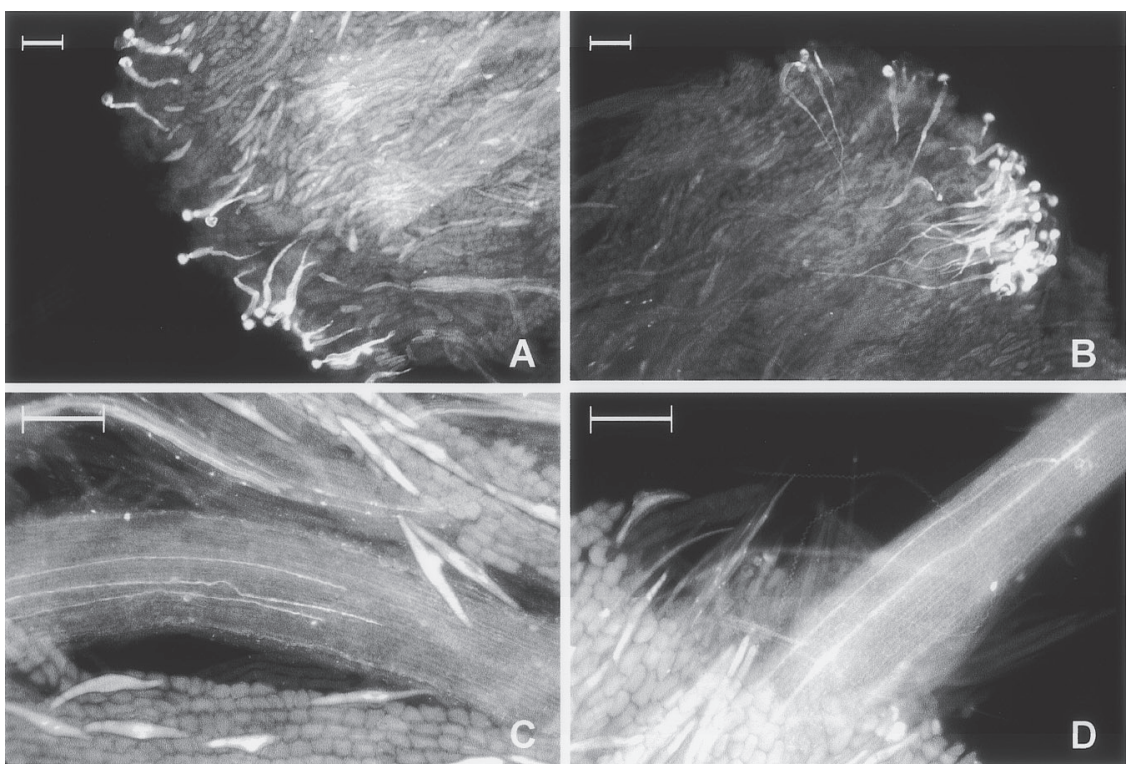

Fig. 1. Pollen germination and pollen tube growth in Cornus florida 'Cherokee Princess' styles stained with aniline blue and viewed using fluorescence microscopy. (A) Germinating pollen grains on surface of stigma, $4 \mathrm{~h}$ after self-pollination. (B) Pollen tube elongation on stigmatic surface, $4 \mathrm{~h}$ after crosspollination. (C) Three pollen tubes in stylar transmitting tissue, $24 \mathrm{~h}$ after cross-pollination. (D) Two pollen tubes emerging from base of style, $48 \mathrm{~h}$ after cross-pollination. 
studies in which self-pollinations have resulted in low or no seed set (Ohta, 1971; Orton, 1983; Reed, 1999). This study confirms this incompatibility and provides evidence of a gametophytic self-incompatibity system. Pollen freely germinated on the stigmatic surface following self-pollination, but pollen tubes grew slower than those resulting from cross-pollination. The slower pollen tube growth and the failure of pollen tubes from self-pollinations to reach the base of the style are indicative of gametophytic self-incompatibility. Based on the presence of bicellular pollen in Cornus (Brewbaker, 1967), this is the self-incompatibility system that is predicted for this species. Results of this study indicate that it is not necessary to emasculate $C$. florida flowers before making controlled cross-pollinations.

Time of stigma receptivity. Pollen germination was observed on at least $90 \%$ of the 'Cherokee Princess' stigmas pollinated from $1 \mathrm{~d}$ before to $1 \mathrm{~d}$ after anthesis (Table 2). Numbers of germinated pollen grains present on stigmas pollinated over this 3 -d period were similar. The percentage of stigmas with germinated pollen and the mean number of germinated grains were lower when pollinations were made 2 or $3 \mathrm{~d}$ after anthesis. By $3 \mathrm{~d}$ after anthesis, pollen germination was observed on only $20 \%$ of the stigmas.

Differences in pollen tube lengths were also noted among pollination times. Pollen tubes from flowers pollinated $1 \mathrm{~d}$ before to $1 \mathrm{~d}$ after anthesis were similar in length to each other, and to pollen tubes from crosspollinations collected $24 \mathrm{~h}$ after pollination in the self-incompatibility experiment (Table 2; Fig. 2). Pollen tube growth was reduced in pollinations made 2 to $3 \mathrm{~d}$ after anthesis. Pollen tubes from flowers pollinated $3 \mathrm{~d}$ after anthesis were about one-half the length of those from flowers pollinated 2 to $4 \mathrm{~d}$ earlier.

Since the individual flowers of a $C$. florida inflorescence open over a 2 - to 3 -week period, obtaining maximum number of seeds may require multiple pollinations of an individual inflorescence. Results of this study indicate that stigmas of C. florida 'Cherokee Princess' are highly receptive to pollen from the day before anthesis to the day after anthesis. Some stigmas may be receptive $2 \mathrm{~d}$ after anthesis, but little seed set is expected from flowers pollinated $3 \mathrm{~d}$ or more after anthesis. Stigma receptivity prior to $1 \mathrm{~d}$ before anthesis was not tested. For cross-pollinations, stigma receptivity prior to anthesis is irrelevant since self-incompatibility eliminates the need to emasculate flowers.

A study of the effect of multiple applications of pollen on seed set in C. florida 'Cherokee Princess', 'Cherokee Brave', 'Cherokee Chief', and 'Barton' determined that seed set was the same when flowers were pollinated every other day as when pollen was applied daily during the first $12 \mathrm{~d}$ of flowering (Reed, 1999). Less frequent pollinations resulted in reduced seed set. These findings concur with evidence presented in the current study that stigmas receptivity begins to decrease by two days after anthesis. In the absence of emasculations, it appears that dogwood flowers must

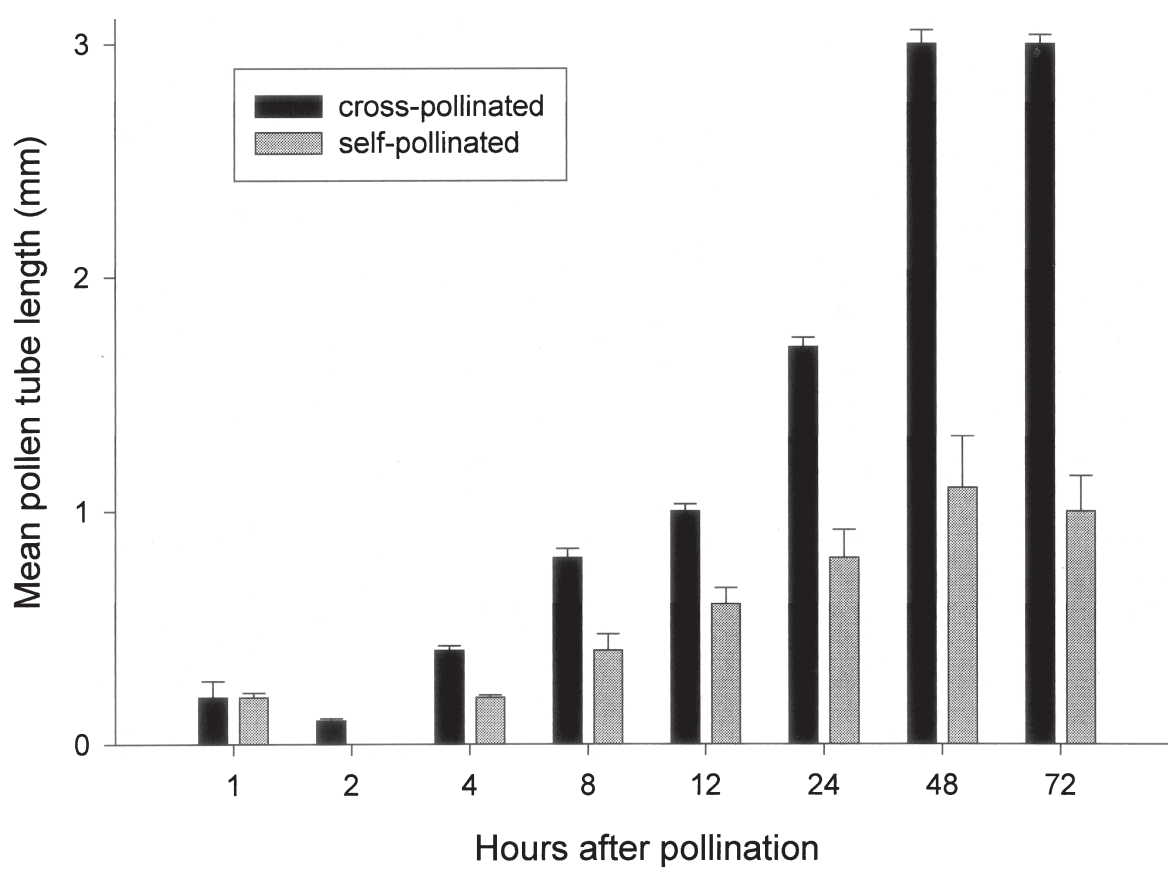

Fig. 2. Pollen tube growth following cross- and self-pollination of Cornus florida 'Cherokee Princess'.

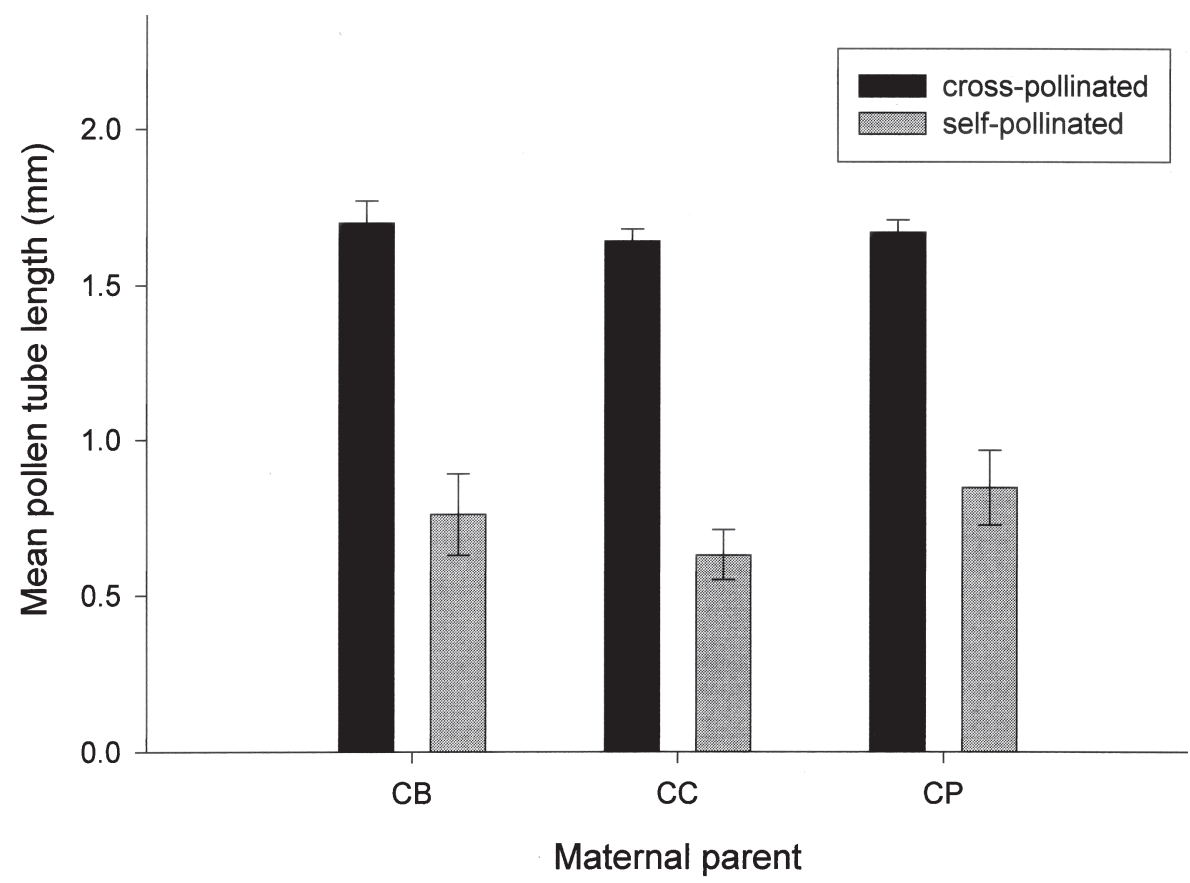

Fig. 3. Pollen tube lengths $24 \mathrm{~h}$ after cross- and self-pollinations of three Cornus florida cultivars. $\mathrm{CB}=$ 'Cherokee Brave'; $\mathrm{CC}=$ 'Cherokee Chief'; $\mathrm{CP}=$ 'Cherokee Princess'.

Table 2. Pollen germination and pollen tube length $24 \mathrm{~h}$ after pollination in C. florida 'Cherokee Princess' cross-pollinated over a 5-d period.

\begin{tabular}{lccc}
\hline Time of pollination & $\begin{array}{c}\text { Stigmas with } \\
\text { germinated pollen }(\%)^{\mathrm{z}}\end{array}$ & $\begin{array}{c}\text { Mean pollen germination } \\
\text { rating }(\text { range })^{\mathrm{y}, \mathrm{x}}\end{array}$ & $\begin{array}{c}\text { Mean length of } \\
\text { pollen tubes }(\mathrm{mm})\end{array}$ \\
\hline 1 d prior to anthesis & 100 & $2.3 \mathrm{~b}$ & $1.7 \mathrm{a}$ \\
Day of anthesis & 90 & $2.6 \mathrm{ab}$ & $1.6 \mathrm{a}$ \\
1 d after anthesis & 100 & $4.0 \mathrm{a}$ & $1.7 \mathrm{a}$ \\
$2 \mathrm{~d}$ after anthesis & 60 & $1.5 \mathrm{~b}$ & $1.2 \mathrm{~b}$ \\
$3 \mathrm{~d}$ after anthesis & 20 & $1.0 \mathrm{~b}$ & $0.8 \mathrm{~b}$ \\
\hline
\end{tabular}

${ }^{2} \mathrm{n}=10$.

${ }^{y} 1=1-25 ; 2=26-50-; 3=51-75 ; 4=76-100 ; 5=$ more than 100 germinated pollen grains; includes only those flowers in which pollen germination was observed.

${ }^{x}$ Values within a column followed by the same letter do not differ sifgnificantly according to Fischer's least significant difference text $(P \leq 0.05)$. 


\section{Breeding, Cultivars, Rootstocks, \& Germplasm Resources}

be cross-pollinated within 1 or $2 \mathrm{~d}$ of opening for pollinations to be effective. If maximum seed set from each inflorescence is needed, as when working with young plants with limited number of inflorescences, pollinations should be repeated every other day.

\section{Literature Cited}

Ascher, PD. 1976. Self-incompatibility systems in floriculture crops. Acta Hort. 63:205-215.

Brewbaker, J.L. 1957. Pollen cytology and selfincompatibility systems in plants. J. Hered. 48:271-277.

Brewbaker, J.L. 1959. Biology of the angiosperm pollen grain. Ind. J. Genet. Plant Breed. 19:121-133.

Brewbaker, J.L. 1967. The distribution and phylogenetic significance of binucleate and trinucleate pollen grains in the angiosperms. Amer. J. Bot. 54:1069-1083.

de Nettancourt, D. 1977. Incompatibility in angiosperms. Springer-Verlag, Berlin.

Dirr, M.A. 1998. Manual of woody landscape plants. Stipes Publishing, Champaign, Ill.

Eyde, R.H. 1988. Comprehending Cornus: Puzzles and progress in the systematics of the dogwood. Bot. Rev. 54:233-351.

Gunatilleke, C.V.S. and I.A.U.N. Gunatilleke. 1984. Some observations on the reproductive biology of three species of Cornus (Cornaceae). J.Arnold Arbor. 65:419-427.

Johansen, D.A. 1940. Plant microtechnique. McGraw-Hill. New York.

Hummel, R.L., P.D. Ascher, and H.M. Pellett. 1982. Genetic control of self-incompatibility in redosier dogwood. J. Hered. 73:308-309.

Martin, F.W. 1959. Staining and observing pollen tubes in the style by means of fluorescence microscopy. Stain Technol. 34:125-128.

Meehan, T. 1893. Contributions to the life histories of plants. Proc. Acad. Nat. Sci. 1892:366-386.

Mmbaga, M.T. and H. Sheng. 2001. Host resistance to Microsphaera pulchra in dogwood. Proc. Southern Nursery Res. Conf. 46:294-297.

Ohta, Y. 1971. Self-incompatibility in Cornus florida and C. kousa. Rep. Kihara Inst. Biol. Res. 22:14-15.

Orton, E.R., Jr. 1983. Propagation of Cornus florida forma rubra by seed-The process and potential. Proc. Intl. Plant Prop. Soc. 32:482-489.

Reed, S.M. 1999. Development of a labor-efficient hand pollination procedure for flowering dog- wood. J. Environ. Hort. 17:92-94.

Santamour,F. S., Jr. and A. J. McArdle. 1985. Cultivar checklists of the large-bracted dogwoods: Cornus florida, C. kousa, and C. nuttallii. J. Arbor. 11:29-36.

Sherald, J.L., T.M. Stidham, J.M. Hadidian, and J.E. Hoeldtke. 1996. Progression of the dogwood anthracnose epidemic and the status of flowering dogwood in Catoctin Mountain Park. Plant Dis. 80:310-312.

Sinclair, W.A., H.H. Lyon, and W.T. Johnson. 1987. Diseases of trees and shrubs. Comstock, Ithaca, N.Y.

Thaler, G.R. and R.C. Plowright. 1980. The effect of aerial insecticide spraying for spruce budworm control on the fecundity of entomophilous plants in New Brunswick, Canada. Can. J. Bot. 58:2022-2027.

Windham, M.T., E.T. Graham, W.T. Witte, J.L.Knighten, and R.N. Trigiano. 1998. Cornus florida 'Appalachian Spring': A white flowering dogwood resistant to dogwood anthracnose. HortScience 33:1265-1267.

Windham, M.T., R.N. Trigiano, W.T. Witte, and P.C. Flanagan. 2000. New dogwood cultivars resistant to powdery mildew. Proc. Southern Nursery Res. Conf. 45:204-206. 